\title{
Karakteristik Sains dalam Pemikiran Filosofis Kontemporer (Tinjauan Filsafat Ilmu-Ilmu Keislaman)
}

\author{
Fu`ad Arif Noor \\ Mahasiswa S3 Studi Islam, konsentrasi PAUDI \\ Pascasarjana UIN Sunan Kalijaga Yogyakarta \\ Email: fuad.arif.noor@gmail.com
}

\begin{abstract}
Science becomes a furqon/criterion, distinguishing between the quality of the creature, even the quality of the man himself. Science is intended as an appetizer reality, then the name is a reality not only in the form of objects, phenomena, facts, data concrete empirical. So, we need approaches or different methods, and not enough to just rely on the senses, instinct and sheer human rationality. Moreover, basically humans also have the potential tool if used optimally can understand and uncover the whole truth of reality. Philosophy of Science today is better known as a vehicle for interactive dialogue between philosophy and science. Science is "fertile ground" for the study of philosophy (Philosophy of Science), and the philosophy is the foundation that is very useful for science in progress-progress. Hence the development and progress of the Philosophy of Science is inseparable from the development and progress of science, and vice versa.Philosophy of Science arable fields more focused on the components of ontology, epistemology, and axiology science. Similarly to the sciences of Islamic understanding of the construction philosophy can not be separated from these three components (ontology, epistemology, and axiology) can provide the basis for the review and development of sciences of Islamic.
\end{abstract}

Keywords : Characteristics of Analytical, Scientific Contemporary Pbilosophy.

\section{Pendahuluan}

Ilmu merupakan fenomena menarik dalam kehidupan manusia, sebab ilmulah yang secara prinsip dapat membedakan antara makhluk tingkat rendah dengan makhluk tingat tinggi, yaitu manusia. Ilmu menjadi furqon, pembeda kualitas antara makhluk, bahkan kualitas antara manusia sendiri. Persoalan aktual dan faktual yang dihadapi adalah ilmu manusia terhenti pada pemahaman atas gejala konkrit-empirik dan terbatas pada hasil pemahaman indera, naluri dan rasionalitas semata-mata.

Ilmu yang berada dalam akal manusia akan menjadi dahsat evolutif, manakala mampu berubah progresif kearah kemajuan yang kontemporer. Akal yang agamis bukan terus regresif yang bersifat mundur, tetapi bagaimana dengan akal agama menjadi sempurna dan kuat rabmatan lil alamin (rahmat bagi makhluk alam semesta). Maka menjadi tugas akal yang agamis itu mampu mensinergikan bermula dari kebebasan berfikir kemudian mencari justifikasi (putusan berdasarkan hati nurani) sampailah pada kebenaran yang diakui bersama. Definisi ilmiah yang terhenti pada kriteria persyaratan baku, seperti harus sistematik, terstruktur dengan runtut, diperlukan kejelasan metodologis, serta rasional, menunjukkan bahwa kebenaran hanya dianggap syah apabila ditemukannya kriteria-kriteria tersebut. Padahal kalau berpandangan bahwa ilmu adalah jalan penyingkap menuju kebenaran tersebut dapat dicapai dengan berbagai cara, 
tergantung tingkat realitas yang hendak disingkapkan, maka definisi tersebut diatas harus dikritik dan pasti memerlukan revisi.

Padahal harus diakui bahwa ilmu memang dimaksudkan sebagai pembuka realitas, maka yang namanya realitas tidak hanya yang berupa benda, fenomena, fakta, data konkrit empirik. Banyak hal dalam kehidupan manusia yang merupakan realitas nonempirik bahkan meta-empirik. Sehingga diperlukan cara pendekatan atau metode yang berbeda, dan tidak cukup hanya mengandalkan indera, naluri dan rasionalitas manusia semata-mata. Apalagi pada dasarnya manusia juga memiliki potensi alat yang kalau dimanfaatkan secara optimal dapat memahami dan menyingkapkan kebenaran seluruh realitas.

Pada galibnya, ilmu dapat berkembang atas dasar optimalisasi potensi kemanusiaan, ilmu empirik yang merupakan upaya manusia menyingkapkan realitas fisik dan biologis sekalipun, dapat berkembang karena optimalisasi indera, naluri dan rasio. Padahal manusia masih memiliki potensi hati nurani dan imajinasi intuisi yang kalau diberdayakan akan menjadi kekuatan luar biasa dalam memahi kebenaran tingkat human, dan transendental. ${ }^{1}$

Selain hal tersebut di atas ada alasan yang lebih konvensional yang berpendapat untuk memperluas ruang lingkup lapangan yang akan dibahas di bawah judul filsafat kontemporer. Jika, karena memang ini terjadi, istilah filsafat modern konvensional digunakan untuk memperpanjang kira-kira sampai akhir abad kesembilan belas, maka istilah filsafat kontemporer dapat berguna disediakan untuk mencakup seluruh rentang filsafat abad kedua puluh. ${ }^{2}$ Dalam kajian ini penulis memaparkan perihal Filsafat Analitik sebagai ciri khas filsafat kontemporer, dan Filsafat ilmu-ilmu Keislaman dalam Pemikiran Kontemporer.

\section{Pembahasan}

\section{A. Filsafat Analitik sebagai Ciri Khas Filsafat Kontemporer}

Perhatian pada fakta bahwa fitur yang luar biasa dari filsafat kontemporer adalah munculnya filsafat analitik ke posisi dominasi. Ekspresi Filsafat analitik seperti halnya dengan banyak label klasifikasi, tidak dapat diberikan tunggal, disepakati secara universal, definisi yang tepat. Hal ini dapat digunakan dalam indra yang lebih luas atau sempit. Istilah filsafat analitik dapat digunakan dalam filsafat kontemporer untuk menutupi jenis analisis yang dilakukan oleh George E. Moore. ${ }^{3}$ Di sisi lain, istilah filsafat analitik dapat digunakan lebih tepat dan sesuai dalam mencirikan filsafat kontemporer ini. ${ }^{4}$

\footnotetext{
1 Achmad Charris Zubair, Dimensi Etik dan Ilmu Pengetabuan Manusia Kajian Filsafat Ilmu, (Yogyakarta ; Lembaga Studi Filsafat Islam (LESFI), 2002), Hal. v-vi.

${ }^{2}$ Milton K. Munitz, Contemporary Analytic Philosophy (London, MACMILLAN PUUBLISHING: 1981), hal. 1-3.

${ }^{3}$ Ibid., hal.4-5.

${ }^{4}$ Ibid.
} 
Wilayah Bahasa, budaya, cara berfikir dan agama sangat ditentukan oleh tata nilai dan adat kebiasaan budaya masing-masing, sehingga sulit untuk ditarik garis lurus yang dapat menyamaratakan antara satu dengan yang lainnya. Oleh karena itu pengalaman beragama hampir dapat dipastikan dipengaruhi juga oleh latar belakang keluarga, pendidikan, ekonomi, lingkungan dan seterusnya. ${ }^{5}$

Dalam hal ini prinsip umum yang harus dibangun adalah proyeksi dialog komunikatif bukan situasi konflik antar agama, budaya dan peradaban, dalam rangka menghadapi berbagai kemungkinan perubahan yang lebih dahsat di masa mendatang perlu lebih dikedepankan daripada hanya sekedar mengeklaim kebenaran tunggal agama-agama yang ada dengan implikasi ketertutupan dan ekslusiftas. Secara umum, ada tiga jenis tema yang diperhatikan secara khusus dalam filsafat analitik kontemporer serta karya beberapa filsuf pragmatis. ${ }^{6}$

1. Sebuah studi tentang peran bahasa dalam komunikasi dan pemikiran; dan, khususnya, masalah bagaimana mengidentifikasi, mencapai, atau memastikan adanya makna dalam penggunaan bahasa.

2. Pemeriksaan logika penyelidikan atau metodologi, sejauh ini ada hubungannya dengan mengevaluasi berbagai teknik dan kondisi untuk mencapai keyakinan yang benar dan dibenarkan klaim pengetahuan.

3. Pemeriksaan filosofis sumber daya logika formal di modern, bentuk direvitalisasi, dan beberapa cara di mana sumber daya tersebut dapat diterapkan dalam membantu memecahkan berbagai masalah filosofis.

Ketiga tema yang berhubungan erat itu secara spesifik interkoneksi mereka berjenis dan menerima perbedaan jenis dan jumlah perhatian atau penekanan. Ada satu fitur umum, salah satu penekanan karakteristik yang dimiliki semua filsafat analitik dan beberapa filsuf pragmatis. Ini terdiri dalam perhatian penggunaan bahasa sebagai media komunikasi pemikiran, dan untuk berbagai kondisi dan sumber daya, bahasa membuat tersedia untuk komunikasi tersebut. Dalam hubungan ini, perhatian khusus ditampilkan untuk masalah makna. Apa cara untuk mencapai atau mengasumsikan kehadiran makna dalam penggunaan bahasa? Apakah ada kondisi tertentu untuk kebermaknaan yang harus dipenuhi? cara apa yang tersedia untuk membuat eksplisit dan jelas makna dan penggunaan berbagai ekspresi linguistik? Mengingat kegagalan dan kesulitan dalam mencapai menggunakan bahasa yang jelas, apa standar dan teknik untuk mencapai klarifikasi?. Upaya untuk menjawab pertanyaan-pertanyaan seperti ini merupakan karakteristik filsafat kontemporer. ${ }^{7}$

Konsepsi ajaran agama yang besifat inklusif (rabmatan lil alamin) dengan muatan nuansa-nuansa pemikiran kontemporer jauh dikdepankan daripada hal. 103-104.

${ }_{5}^{5}$ M. Amin Abdullah, Filsafat Kalam di Era Postmodernisme (Yogyakarta: Pustaka Pelajar, 1997),

${ }^{6}$ Ibid, hal. 8-9.

${ }^{7}$ Ibid., hal. 10-11. 
sekedar megedepankan simbul-simbul dan kelembagaan agama yang seringkali memang sangat terasa superfisial dan partikularistik. ${ }^{8}$

\section{B. Filsafat Ilmu-ilmu Keislaman dalam Pemikiran Kontemporer}

Koento Wibisono mengatakan bahwa Filsafat Ilmu (Philosophy of Science) merupakan salah satu cabang filsafat, sebagai penerusan pengembangan Filsafat Pengetahuan (Philosophy of Knowledge/Epistemology), yang objek sasarannya adalah ilmu atau pengetahuan ilmiah sebagai a higher level of knowledge. ${ }^{9}$ Noeng Muhadjir menambahkan bahwa objek Filsafat Ilmu itu dapat berupa substansi ilmu yaitu fakta/kenyataan dan kebenaran, dan instrumentasinya yaitu uji konfirmasi dan logika inferensi. ${ }^{10}$

Kata sains atau Ilmu berasal dari bahasa Arab yang berarti: pengetahuan. ${ }^{11}$ Filsafat ilmu adalah segenap pemikiran reflektif terhadap persoalan-persoalan mengenai segala hal yang menyangkut landasan ilmu maupun hubungan ilmu dengan segala segi dari kehidupan manusia. ${ }^{12}$ Filsafat ilmu disebut juga sebagai theory of science atau science of science. Bahkan filsafat ilmu disebut juga meta science yaitu suatu ilmu yang mengatasi ilmu-ilmu yang lain. ${ }^{13}$

Filsafat Ilmu dewasa ini lebih dikenal sebagai wahana dialog interaktif antara filsafat dengan ilmu. Ilmu merupakan "lahan subur" bagi kajian filsafat (Filsafat Ilmu), dan filsafat adalah fondasi yang sangat berguna bagi ilmu dalam mencapai kemajuan-kemajuannya. Karenanya perkembangan dan kemajuan Filsafat Ilmu tidak terlepas dari perkembangan dan kemajuan ilmu, dan begitu juga sebaliknya. ${ }^{14}$ Sebagai salah satu rumpun keilmuan yang telah berkembang dalam tradisi intelektual masyarakat Islam, Ilmu- ilmu Keislaman dewasa ini semakin berhadapan dengan tantangan filosofis yang lebih serius dari masa-masa sebelumnya.

Amin Abdullah menegaskan bahwa Ilmu-ilmu Keislaman lebih merupakan kegiatan "keilmuan", bukan sekedar kegiatan keagamaan. Karena itu telaah Filsafat Ilmu terhadap bangunan atau rancang-bangun keilmuan Ilmu-ilmu Keislaman tersebut perlu dipertimbangkan. ${ }^{15}$ Pernyataan ini relevan dengan sinyalemen Koento Wibisono bahwa urgensi pengembangan ilmu-ilmu tidak hanya berdasarkan metodologi yang dibatasi oleh context of justification, tetapi juga

\footnotetext{
${ }^{8}$ M. Amin Abdullah, Ibid., hal. 112.

${ }^{9}$ Koento Wibisono, Filsafat Ilmu: Sebagai Dasar Pengembangan Ilmu Pengetabuan, (Yogyakarta: LP3 UGM \& Intan Pariwara (Klaten), 1997), hal, 7.

${ }^{10}$ Noeng Muhadjir, Filsafat Ilmu, Edisi II, (Yogyakarta: Rake Sarasin, 2001), hal, 6.

11 A.W. Munawwir, Kamus al-Munawwir (Surabaya: Pustaka Progresif, 1997), hal. 966.

12 The Liang Gie, Pengantar Filsafat Ilmu (Yogyakarta: Liberty, 2000), hal. 88.

13 Imam Masykuni, Filsafat Ilmu: Sebuah Dasar Bagi Pemahaman dan Pengembangan Ilmu (Jurnal Ilmu dan Budaya, 1985), hal. 138.

${ }^{14}$ Fuad, Kebenaran Ilmiah dalam Perspektif Positivisme Logis, Makalah Mata Kuliah Filsafat Ilmu pada Program Doktor Ilmu Filsafat UGM, Yogyakarta, 2005.

${ }^{15}$ M. Amin Abdullah, Studi Agama, (Yogyakarta: Pustaka Pelajar, 1996), hal. 102.
} 
atas dasar heuristik yang bergerak dalam context of discovery. ${ }^{16}$ Karena itu landasan filosofis (ontologis, epistemologis, dan aksiologis) ilmu-ilmu yang ada sekarang termasuk Ilmu-ilmu Keislaman tidak harus dipegang/diyakini (dianut) secara absolut dan taken for granted. Masih terdapat alternatif landasan filosofis lain yang dapat dijadikan sandaran bagi kegiatan-kegiatan keilmuan dalam rangka mencari solusi bagi pemahaman baru dalam rangka mengatasi segala kemapanan yang sudah berlaku selama ini.

Pemahaman tersebut relevan dengan pandangan sejumlah pemikir Islam kontemporer yang sudah mulai merintis alternatif pendekatan baru dalam memahami khazanah keilmuan Islam yang bertolak dari perspektif realitas masyarakat Islam masa kini. Yusuf al-Qardlowi, misalnya menegaskan pentingnya pelaksanaan ijtihad dalam masalah-masalah baru akibat perubahan zaman dan situasi, sebagai fardhu kifayah bagi umat Islam. ${ }^{17}$ Ahmad Hasan menekankan keharusan penambahan dan penafsiran ulang terhadap hukumhukum yang disediakan oleh sumber al-Qur'an-Shunnah di masa Rasulullah dalam rangka perluasan pemahaman mencakup persoalan-persoalan baru yang harus ditemukan jawabannya. ${ }^{18}$ Demikian juga menurut Fazlur Rahman, bukanlah suatu keharusan untuk menerima suatu penafsiran tertentu untuk selamanya, akan selalu ada ruang dan keharusan untuk penafsiran-penafsiran baru sebagai proses yang terus berlanjut. ${ }^{19}$

Pemahaman tentang Epistemologi yang berkembang dalam wacanawacana Pemikiran Islam Kontemporer dapat ditemukan dari beberapa eksponen rekonstruksionis Islam seperti S.H. Nasr, S.M.N. al-Attas, dan terutama Ziauddin Sardar. Pada prinsipnya mereka mempunyai tujuan yang sama, yaitu merumuskan sebuah konstruksi Epistemologi Islam yang ideal, yang relevan dengan nilai-nilai Islam, kendati dalam beberapa segi tertentu mereka saling berbeda.

Nasr beranjak dari perspektif sufi, mengembangkan konsep epistemologi berbasis metafisika, dan dengan tegas mengecam dan membeberkan kelemahan-kelemahan dan krisis yang dihadapi epistemologi modern. ${ }^{20}$ Epistemologi modern memiliki karakteristik yang sekuler, sebagai antitesis terhadap nilai-nilai tradisi dan agama (ajaran ilahi), yang hanya mengandalkan otoritas akal dan pengalaman manusia sebagai sumber bagi segala bentuk

${ }^{16}$ Koento Wibisono, op. cit.,hal. 8.

17 Yusuf al-Qardlowi, Membumikan Syari'at Islam, terjemahan M. Zakki dan Yasir Tajid, (Surabaya: Dunia Ilmu, 1997), hal. 290.

18 Ahmad Hasan, Pintu Ijtihad Sebelum Tertutup, terjemahan Agah Garnadi, (Bandung: Pustaka, 1984), hal. 103.

19 Adnin Armas, "Westernisasi dan Islamisasi Ilmu", dalam Islamia, Thn. I, no. 6, Juli - September $2005,15$.

20 Selengkapnya lihat: Seyyed Hossein Nasr, Pengetahuan dan Kesucian, Terjemahan Suharsono dkk., (Yogyakarta: Pustaka Pelajar dan CSIS, 1997); Seyyed Hossein Nasr, Encounter of Man and Nature, London: Allen and Unwin, 1968. 
pengetahuan yang paling absah (valid). Keunggulan ilmu pengetahuan (dan teknologi) dipandang sebagai satu-satunya simbol kemajuan peradaban.

Karena itu Al-Attas menyatakan bahwa tantangan terbesar yang secara diam-diam dihadapi oleh umat Islam jaman sekarang adalah tantangan pengetahuan, yang disebarluaskan ke seluruh penjuru dunia oleh peradaban Barat. ${ }^{21}$ Sardar menilai bahwa peradaban ditentukan oleh epistemologi karena epistemologi menuntun semua aspek studi manusia dari filsafat dan ilmu murni sampai ilmu-ilmu sosial. Epistemologi merupakan operator utama untuk mengubah bayangan Pandangan Dunia menjadi kenyataan. ${ }^{22}$ Karena itu kegemilangan masa depan peradaban Islam mustahil dapat diraih tanpa upaya rekonstruksi Epistemologi Islam.

Menurut Sardar, sains (ilmu) adalah sarana pemecahan masalah mendasar dari setiap peradaban. Sebagai realisasi eksternal suatu epistemologi, sains membentuk lingkungan fisik, intelektual, dan budaya serta memajukan cara produksi ekonomis yang dipilih oleh suatu peradaban. Singkatnya, sains adalah sarana yang pada gilirannya mencetak suatu peradaban, sebagai ungkapan fisik dari pandangan-dunianya. ${ }^{23}$

Konsep Epistemologi ketiga tokoh tersebut, dengan keunikannya masingmasing, dapat dikontribusikan untuk pengembangan Ilmu-ilmu Keislaman pada masa sekarang. Mereka telah menawarkan gagasan-gagasan baru tentang Epistemologi Ilmu atau Filsafat keilmuan, yang dapat dijadikan sebagai landasan konstruktif untuk membangun kerangka Filsafat Ilmu-ilmu Keislaman yang relevan dengan tuntutan kebutuhan masyarakat Islam. Upaya pengembangan Ilmu-ilmu Keislaman tidak mungkin dapat dilakukan tanpa Filsafat Ilnu-ilmu Keislaman yang komponen-komponen utamanya dapat digali dari konstruksi Filsafat Keilmuan para pemikir Islam kontemporer tersebut.

Bidang garapan Filsafat Ilmu lebih terarah pada komponen-komponen ontologi, epistemologi, dan aksiologi ilmu. ${ }^{24}$ Demikian halnya dengan Ilmu-ilmu Keislaman, pemahaman tentang konstruksi filsafatnya tidak bisa terlepas dari ketiga komponen tersebut (ontologi, epistemologi, dan aksiologi) dapat memberikan landasan bagi penelaahan dan pengembangan Ilmu-ilmu Keislaman, baik landasan ontologis (esensi ilmu, esensi kebenaran ilmu, esensi objek ilmu), landasan epistemologis (cara/metode ilmu, sumber ilmu,

\footnotetext{
${ }^{21}$ S.M.N al-Attas, Islam dan Sekularisme, (Bandung: Pustaka, 1981), hal. 195.

22 Ziauddin Sardar, Masa Depan Islam, Terjemahan Rahmani Astuti, (Bandung : Pustaka, 1987), hal. 74; Ziauddin Sardar, Rekayasa Masa Depan Peradaban Muslim, Terjemahan Rahmani Astuti, Bandung : Mizan, 1986, hal. 41. 1987), hal. 161.

${ }^{23}$ Ziauddin Sardar, Masa Depan Islam, Terjemahan Rahmani Astuti, (Bandung: Pustaka,

${ }^{24}$ Koento Wibisono, Filsafat Ilmu: Sebagai Dasar Pengembangan Ilmu Pengetabuan, (Yogyakarta: LP3 UGM \& Intan Pariwara (Klaten), 1997), hal. 7.
} 
pertanggungjawaban/pembuktian ilmu), dan landasan aksiologisnya (nilainilai/tujuan ilmu).

Dalam perspektif filsafat keilmuan para pemikir Islam Kontemporer, ketiga landasan tersebut memiliki keunikan tersendiri dan berbeda dari konsep para filsuf Ilmu Barat/modern, sebagaimana yang tercermin dari pemikiran Sardar, Nasr, dan al-Attas berikut ini.

\section{Landasan Ontologis Ilmu}

Sardar mengatakan bahwa ciri yang unik dari sains (ilmu) Islam adalah penekanannya pada kesatuan agama dengan sains, pengetahuan dan nilai, fisika dan metafisika. Pada prinsipnya, ilmu merupakan salah satu dari keseluruhan konsep-konsep Islam yang sangat fundamental, sebagai suatu agen formatif yang membentuk pandangan Peradaban Islam. ${ }^{25}$

Konsep ilm (ilmu) menyatukan hampir seluruh bentuk pengetahuan, dari pengamatan murni sampai metafisika yang paling tinggi. ' $I / m$ merupakan sistem pengetahuan yang di dalamnya terkandung berbagai bentuk pengetahuan, baik pengetahuan-pengetahuan metafisik, empiris, maupun eksakta. Bentuk-bentuk pengetahuan tersebut tidak dapat dipisahkan satu sama lain, tetapi harus dipahami di dalam sebuah kerangka kesatuan. "Semua bentuk pengetahuan tersebut saling terkait dan secara organis dihubungkan oleh jiwa wahyu Al-Qur'an yang selalu hidup."26

Adapun menurut al-Attas, sains Islam bertentangan dengan sains modern karena sains modern secara legitim telah mereduksi setiap bentuk realitas kepada otoritas inderawi, fenomena empiris, dan mengingkari realitas metaempiris sehingga menyiratkan penolakan terhadap keberadaan Tuhan. ${ }^{27}$ Pemikiran Sardar dan al-Attas, keduanya berbeda dengan pemikiran Barat/modern. Sardar bahkan berbeda dengan al-Ghazali yang oleh Fazlur Rahman dituding telah mendikotomikan ilmu agama dengan ilmu sekular. ${ }^{28}$

\section{Landasan Epistemologis Ilmu}

Sardar menegaskan bahwa Epistemologi Islam merupakan parameter yang menentukan: "apa yang mungkin diketahui dan harus diketahui, apa yang mungkin diketahui tetapi lebih baik dihindari, dan apa yang sama sekali tidak mungkin untuk diketahui". ${ }^{29}$

Epistemologi Islam menekankan pada keseluruhan pengalaman dan realitas, dan mendukung bukan hanya satu melainkan sejumlah cara yang

\footnotetext{
${ }^{25}$ Ziauddin Sardar, op.cit, hal. 27.

26 Ibid.,hal. 104.

${ }^{27}$ S.M.N al-Attas, Islam dan Filsafat Sains, Terjemahan Saiful Muzani, (Bandung: Mizan, 1995),

${ }^{28}$ Fazlur Rahman, Islam and Modernity, (Chicago: The University of Chicago Press : 1984),

29 Ziauddin Sardar, op.cit., hal. 85.
} hal. 26-27. hal. 96, 158. 
berbeda-beda dan saling terkait untuk mengkaji dan memahami pengetahuan, selama tunduk pada nilai-nilai wahyu Al-Qur'an yang kekal, yang merupakan tonggak Peradaban Islam. ${ }^{30}$

Sardar menambahkan, ilm juga dapat diperoleh dari wahyu, akal, pengamatan, serta intuisi, dan dari tradisi sampai spekulasi teoritis. ${ }^{31}$ Disamping 'ilm itu sebagai sistem pengetahuan, ilm juga sekaligus bersumber dari sebuah sistem yang didalamnya terkandung bagianbagian (wahyu, akal, pengamatan, intuisi, tradisi, dan spekulasi) yang saling terkait dan tidak terpisahkan satu sama lain. Maka wahyu tidak dapat dipahami saling terpisah dengan akal atau intuisi, akal tidak dapat dipahami saling terpisah dengan tradisi atau pengamatan, dan begitu seterusnya.

\section{Landasan Aksiologis Ilmu}

Menurut Nasr, sains Barat itu pada dasarnya adalah sah, tetapi peranan, fungsi dan aplikasinya menjadi tidak sah dan berbahaya karena memisahkan diri sepenuhnya dari bentuk pengetahuan yang lebih tinggi. ${ }^{32}$ Nasr menegaskan bahwa Sains Islam pada prinsipnya bertentangan dengan sains modern karena Sains Islam berorientasi pada sifat unity (kesatupaduan) yang merupakan inti wahyu Islam dan mencerminkan peradaban khas Islam. Karenanya Sains Islam tidak dapat dipahami dari pandangan sains modern, melainkan dari pandangan (perspektif) Islam itu sendiri. ${ }^{33}$ Nasr juga menyeru agar sains Barat harus segera dijauhkan dari wilayah intelektualitas muslim karena telah tercerabut dari nilai-nilai kemanusiaan dan ketuhanan, dan telah menyebabkan kehancuran alam dan manusia. ${ }^{34}$

Al-Attas juga secara terang-terangan mengklaim bahwa Epistemologi Barat - yang seluruhnya bermuatan skeptisisme dan tidak mengenal batas-batas nilai dan etika merupakan antitesis dari Epistemologi Islam. ${ }^{35}$ Sardar bahkan bukan hanya menilai penerapan Sains Barat yang tidak sesuai dan berbahaya, tetapi juga epistemologinya yang secara mendasar bertentangan dangan perspektif Islam. ${ }^{36}$

Sardar menegaskan bahwa Islam benar-benar menjadikan menuntut ilmu (sains) sebagai kewajiban keagamaan, dan menjadi muslim berarti

\footnotetext{
30 Ibid., hal. 104.

31 Ibid., hal. 104.

32 Ibid., hal. 177.

33 Sayyed Hossein Nasr, Sains dan Peradaban di dalam Islam, Terjemahan J. Mahyudin, (Bandung: Pustaka, 1986), hal. 1.

34 Pervez Hoodbhoy, Ikhtiar Menegakkan Rasionalitas: Antara Sains dan Ortodoksi Islam, Terjemahan Sari Meutia, (Bandung: Mizan, 1996), hal. 132-136.

35 Selengkapnya lihat S.M.N al-Attas, Islam dan Filsafat Sains, Terjemahan Saiful Muzani, (Bandung: Mizan, 1995), hal. 28.

36 Pervez Hoodbhoy, op. cit., hal. 132-136.
} 
terlibat aktif dalam pelahiran, pemrosesan, dan penyebaran ilmu. ${ }^{37}$ Pandangan Sardar relevan dengan pendapat Wan Mohd. Nor Wan Daud bahwa di dalam Islam pencarian pengetahuan oleh seseorang bukanlah sesuatu yang tidak mungkin, tetapi harus dan dianggap sebagai kewajiban bagi semua muslim yang bertanggung jawab. ${ }^{38}$

Karena itu, menurut Sardar pencarian 'ilm (ilmu) adalah suatu bentuk ‘badah (pemujaan), sehingga ílm itu dicari demi mematuhi dan untuk menyenangkan Allah SWT. Hubungan antara ilm dengan ibadah mengandung arti bahwa pencarian ilm tidak dapat dilaksanakan jika secara terbuka atau terang-terangan melanggar perintah Allah, atau tidak sesuai dengan petunjuk Allah $S W T{ }^{39}$

Dalam pandangan Sardar, Epistemologi Islam mengandung sebuah konsep yang holistik mengenai pengetahuan ( $\mathrm{ilm}$ ) yang tidak terpisahkan dengan nilai-nilai (aksiologis), terkait dengan fungsi sosialnya, dan dipandang sebagai sebuah ciri dari manusia. Dengan demikian terdapatlah sebuah kesatuan antara manusia dengan pengetahuannya sehingga tidak ada informasi- informasi khusus yang bebas nilai untuk tujuan-tujuan tertentu, atau berakibat perendahan martabat, pengisolasian, dan pengasingan manusia. $^{40}$

Menurut Charles S. Peirce, perkembangan pemikiran manusia dimulai dari belief (keyakinan), babit of mind (kebiasaan pikiran), doubt (keraguan), inquiry (investigasi), dan meaning (makna). Belief merupakan sesuatu yang diyakini kebenarannya, sehingga menjadi dasar bagi seseorang untuk bertindak. Sifat yang ada pada keyakinan, meliputi: proposisi, penilaian, dan adanya kebiasaan dalam berfikir (babit of mind) yang melekat dalam benak seseorang dan selanjutnya diiringi oleh kemunculan doubt. Terdapat dua macam doubt, yaitu genuine doubt (keraguan sejati) dan artificial doubt (keraguan semu). Hanya genuine doubt yang bisa menghantarkan kepada tahapan berikutnya, yakni inquiry. Pelaksanaan inquiry antara lain melalui research. ${ }^{41}$

Menurut Peirce, sebagaimana dikutip Steven, usaha manusia dalam mencari kebenaran melalui beberapa cara, 1) a priori, 2) trial and error, 3) melalui otoritas, 4) melalui metode ilmiah atau investigasi. Metode ilmiah merupakan prosedur yang mencakup berbagai tindakan pikiran, pola kerja,

37 Ziauddin Sardar, Tantangan Dunia Islam abad 21, Terjemahan A.E Priyono dan Ilyas Hasan, (Bandung: Mizan, 1988), hal. 39.

38 Wan Mohd. Nor Wan Daud, Konsep Pengetahuan dalam Islam, Terjemahan Munir, (Bandung: Pustaka, 1997), hal. 65.

39 Ziauddin Sardar, Masa Depan Islam, Terjemahan Rahmani Astuti, (Bandung: Pustaka, 1987), hal. 104.

40 Ziauddin Sardar, Sains, Teknologi dan Pembangunan di Dunia Islam, Terjemahan Rahmani Astuti, (Bandung: Pustaka, 1989), hal. 32.

${ }^{41}$ Milton K. Munitz, Contamporery Analitic Philosophy (New York: Macmillan Publishing Co. Inc, 1981), hal. 34 
tata langkah, dan cara teknis untuk memperoleh pengetahuan baru atau mengembangkan pengetahuan yang ada. Melalui science inilah, pemikiran manusia akhirnya dapat mencapai makna hakiki (meaning) yang pada dasarnya lebih utama daripada kebenaran (truth) karena makna merupakan esensi dan substansi dari berbagai fenomena kehidupan manusia. Sebagai salah seorang peletak dasar pragmatisme, Peirce mengatakan bahwa untuk memastikan makna apakah yang dikandung oleh sebuah konsepsi akali, maka kita harus memperhatikan konsekuensi-konsekuensi praktis apakah yang niscaya akan timbul dari kebenaran konsepsi tersebut. ${ }^{42}$

\section{Catatan Akhir}

Ada tiga jenis tema yang diperhatikan khusus dalam filsafat analitik kontemporer serta karya beberapa filosuf pragmatis :

1. Sebuah studi tentang peran bahasa dalam komunikasi dan pemikiran; dan, khususnya, masalah bagaimana mengidentifikasi, mencapai, atau memastikan adanya makna dalam penggunaan bahasa.

2. Pemeriksaan logika penyelidikan atau metodologi, sejauh ini ada hubungannya dengan mengevaluasi berbagai teknik dan kondisi untuk mencapai keyakinan yang benar dan dibenarkan klaim pengetahuan.

3. Pemeriksaan filosofis sumber daya logika formal di modern, bentuk direvitalisasi, dan beberapa cara di mana sumber daya tersebut dapat diterapkan dalam membantu memecahkan berbagai masalah filosofis.

Perumuskan konsep dasarnya yang bersumber dari kontribusi pemikiran Nasr, al- Attas, dan terutama Sardar tentang trilogi landasan filosofis (Landasan Ontologis Ilmu, Landasan Epistemologis Ilmu, dan Landasan Aksiologis Ilmu). Melalui landasan ontologis tersebut, Filsafat Ilmu-ilmu Keislaman dapat menentukan wilayah objek kajian Ilmu-ilmu Keislaman, yang meliputi aspek-aspek metafisika dan empiris secara integratif. Melalui landasan epistemologisnya, Filsafat Ilmu-ilmu Keislaman dapat mengakomodir keragaman (pluralitas) metodologis (berbagai prosedur atau cara mengkaji ilmu), sesuai dengan kebutuhan intelektual masyarakat Islam. Melalui landasan aksiologisnya, Filsafat Ilmu-ilmu Keislaman dapat mengarahkan dan menuntun pemahaman ontologis dan epistemologis tersebut sesuai dengan nilai-nilai dasar Islam.

Bidang garapan Filsafat Ilmu lebih terarah pada komponen-komponen ontologi, epistemologi, dan aksiologi ilmu. Komponen ini dapat memberikan landasan bagi penelaahan dan pengembangan Ilmu-ilmu Keislaman, baik landasan ontologis (esensi ilmu, esensi kebenaran ilmu, esensi objek ilmu), landasan epistemologis (cara/metode ilmu, sumber ilmu, pertanggungjawaban/pembuktian ilmu), dan landasan aksiologisnya (nilai-nilai/tujuan ilmu).

42 Steven D. Schfersman, “An Introduction to Science: Scientific Thinking and the Scientific Method" dalam http://www.freeinquiry.com/intro-to-sci.html, Januari, 2017. 
Dengan demikian, Filsafat Ilmu-ilmu Keislaman dapat dikembangkan secara berkesinambungan, dalam merespon berbagai kebutuhan intelektual masyarakat Islam. Alternatif pengembangan ini juga dapat dilakukan secara terpadu (integratif), tidak hanya dengan menumbuhkan kesadaran historis untuk menggali khazanah kemajuan intelektual Islam masa lalu, tetapi sekaligus juga dengan merespon kemajuan-kemajuan metodologi masa kini yang relevan dengan nilai-nilai intelektual Islam yang kekal dan universal.

\section{Daftar Rujukan}

Achmad Charris Zubair, Dimensi Etik dan Ilmu Pengetabuan Manusia Kajian Filsafat Ilmu, (Yogyakarta ; Lembaga Studi Filsafat Islam (LESFI), 2002).

Adnin Armas, "Westernisasi dan Islamisasi Ilmu", dalam Islamia, Thn. I, no. 6, Juli September 2005.

Ahmad Hasan, Pintu Ijtihad Sebelum Tertutup, terjemahan Agah Garnadi, (Bandung: Pustaka, 1984).

A.W. Munawwir, Kamus al-Munawwir (Surabaya: Pustaka Progresif, 1997).

Fazlur Rahman, Islam and Modernity, (Chicago: The University of Chicago Press : 1984).

Fuad, Kebenaran Ilmiah dalam Perspektif Positivisme Logis, Makalah Mata Kuliah Filsafat Ilmu pada Program Doktor Ilmu Filsafat UGM, Yogyakarta, 2005.

Imam Masykuni, Filsafat Ilmu: Sebuah Dasar Bagi Pemahaman dan Pengembangan Ilmu (Jurnal Ilmu dan Budaya, 1985).

Koento Wibisono, Filsafat Ilmu: Sebagai Dasar Pengembangan Ilmu Pengetabuan, (Yogyakarta: LP3 UGM \& Intan Pariwara (Klaten), 1997).

M. Amin Abdullah, Studi Agama, (Yogyakarta: Pustaka Pelajar, 1996).

M. Amin Abdullah, Falsafah Kalam Di Era Postmodernisme, (Yogyakarta: Pustaka Pelajar, 1997).

Milton K. Munitz, Contamporery Analitic Philosophy (New York: Macmillan Publishing Co. Inc, 1981).

Noeng Muhadjir, Filsafat Ilmu, Edisi II, (Yogyakarta: Rake Sarasin, 2001).

Pervez Hoodbhoy, Ikbtiar Menegakkan Rasionalitas: Antara Sains dan Ortodoksi Islam, Terjemahan Sari Meutia, (Bandung: Mizan, 1996).

Sayyed Hossein Nasr, Sains dan Peradaban di dalam Islam, Terjemahan J. Mahyudin, (Bandung: Pustaka, 1986).

Seyyed Hossein Nasr, Pengetahuan dan Kesucian, Terjemahan Suharsono dkk., (Yogyakarta: Pustaka Pelajar dan CSIS, 1997);

Seyyed Hossein Nasr, Encounter of Man and Nature, (London: Allen and Unwin, 1968).

Steven D. Schfersman, "An Introduction to Science: Scientific Thinking and the Scientific Method" dalam http://www.freeinquiry.com/intro-to-sci.html, Januari, 2017.

S.M.N al-Attas, Islam dan Sekularisme, (Bandung: Pustaka, 1981).

S.M.N al-Attas, Islam dan Filsafat Sains, Terjemahan Saiful Muzani, (Bandung: Mizan, 1995).

The Liang Gie, Pengantar Filsafat Ilmu (Yogyakarta: Liberty, 2000). 
Wan Mohd. Nor Wan Daud, Konsep Pengetahuan dalam Islam, Terjemahan Munir, (Bandung: Pustaka, 1997).

Yusuf al-Qardlowi, Membumikan Syariat Islam, terjemahan M. Zakki dan Yasir Tajid, (Surabaya: Dunia Ilmu, 1997).

Ziauddin Sardar, Masa Depan Islam, Terjemahan Rahmani Astuti, (Bandung: Pustaka, 1987).

Ziauddin Sardar, Rekayasa Masa Depan Peradaban Muslim, Terjemahan Rahmani Astuti, (Bandung : Mizan, 1986).

Ziauddin Sardar, Sains, Teknologi dan Pembangunan di Dunia Islam, Terjemahan Rahmani Astuti, (Bandung: Pustaka, 1989).

Ziauddin Sardar, Tantangan Dunia Islam abad 21, Terjemahan A.E Priyono dan Ilyas Hasan, (Bandung: Mizan, 1988). 